\title{
流体力を近似した軸方向力を受けるはりの非保存的弾性安定性に関する考察*
}

\author{
藤田 勝久 ${ }^{* 1}$, 後藤 彰秀 ${ }^{* 2}$
}

\section{A Consideration on Nonconservative Elastic Stability of a Beam Subjected to Axial Force Considered to be Fluid Force}

\author{
Katsuhisa FUJITA* ${ }^{* 1}$ and Akihide GOTOU \\ ${ }^{* 1}$ Osaka City Univ., Mechanical \& Physical Engineering, Graduate School of Engineering \\ 3-3-138, Sugimoto, Sumiyoshi-ku, Osaka, 558-8585, Japan
}

\begin{abstract}
The dynamic stability problem of machines and structures is one of the important subjects for a long time. Recently, they are considered to be relatively flexible for loads as they become large-sized and light-weighted. By the way, in the conventional dynamic stability analysis, many problems of the structural analysis have been dealt with as a conservative system. However, in the problems which are acted by fluid forces such as air and water in space structures and marine structures so on, the dynamics of structures are affected by the deflection of the structure. That is, the treatment of a nonconservative system such as a follower force becomes important. In addition, in the structural destruction troubles of machines and structures which have happened in the past, the dynamic instability which the follower force induced may be thought to be one of the causes although the detailed elucidations of troubles have not been done. In this paper, the stability of non-conservative system of a beam is investigated when the fluid force acting on a cantilever subjected to the axial flow is considered to be an axial force. The fundamental study is performed by using the discrete model of 2 degree of freedom systems. Moreover, this is expanded to the continuous system of a cantilever. And, the physical consistency between a discrete model and a continuous one and the effect of damping are discussed.
\end{abstract}

Key Words : Axial Force, Follower Force, Nonconservative Elastic Stability, Flutter, Divergence

\section{1. 緒言}

機械や構造物の動的な安定問題は古くから重要な課題の一つである. とくに最近では，機械や構造物の大形化 や軽量化に伴い，荷重に対して相対的に柔軟な構造物とみなされるようになるに従い，その動的な安定問題がま すます重要視されるようになってきている.

従来の動的な安定解析では, ほとんどの場合, 作用する荷重の方向が構造物の変形の影響を受けないとして解 析されている. 寸なわち, 取り扱われてきた解析の問題は, 多くは力が保存力として扱われる保存系である. しか し最近, 宇宙構造物から海洋構造物に至るまで, 空気や水などの流体の影響を受ける場合の問題が多くなってき ている. これらの流れから受ける流体力は, 構造の変形に伴って力の作用する方向が変化すると考えられる場合 も増加してきている. 寸なわち, 非保存力（従動力）のような力を扱う非保存系としての取り扱いが必要になる. また, 過去に起きた機械, 構造物の事故の中には, 非保存力が作用し引き起こされた不安定振動が主な原因と考 えられる例もあるが, 詳細な解明がなされたわけではない.このような状況下で, 本分野の研究は比較的古くか らすでに問題の提起がなされてきており ${ }^{(1)-(5)}$, さらに引き続いていくつかの研究がなされてきているが(6)-(10), 必ず しも十分とはいえない. 安全な機械や構造物を世の中に送り出していくためには, 非保存力に焦点をあてた研究 も非常に重要となる.

\footnotetext{
* 原稿受付 2011 年 10 月 21 日

${ }^{* 1}$ 正員, フェロー, 大阪市立大学大学院工学研究科機械物理系専攻（广558-8585 大阪府大阪市住吉区杉本 3-3-138)

*2 学生員, 大阪市立大学大学院工学研究科機械物理系専攻

E-mail: fujita@mech.eng.osaka-cu.ac.jp
} 
ここでは, 軸流を受けるはりについて, 流体力を軸方向力とみなして, はりの非保存的安定性について考察す る. 2 自由度系の離散化モデルにより基本的な考察を行い, さらに片持ちはりの連続体モデルについて展開し, 考 察を加える. また, 離散化モデルと連続体モデルの間の物理的な整合性や減衰の影響についても考察する.

\section{2. 理 論}

\section{$2 \cdot 1$ 保存系と非保存系のモデリング}

構造物に作用する流体力としての抗力は，摩擦抗力と圧力抗力に分けられる．流体が構造物の表面を流れると き, 構造物は流体から粘性のために摩擦による抗力を受ける. 構造物が流線形の場合この摩擦による力が支配的 になる. さらに，構造物の表面からの渦や剥離などにより，構造物は流体から圧力差に基づく抗力を受ける. 流 線形でないときこの圧力による力が支配的になる.

ここでは，片持ち支持された一様はりに前述した流体力が作用するとき，これらの流体力を集中荷重と接線方 向の一様分布荷重で近似して，これらが作用寸る際の構造の弾性安定問題を考える. まず，一般的なはりの弾性 安定問題として, 図 1 に示すモデルを考える.

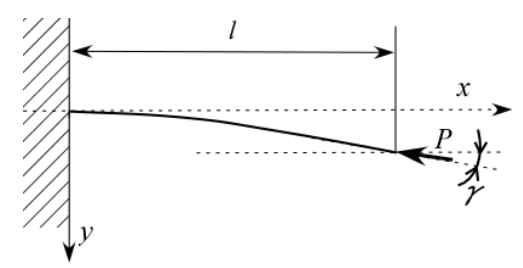

(a) Concentrated load

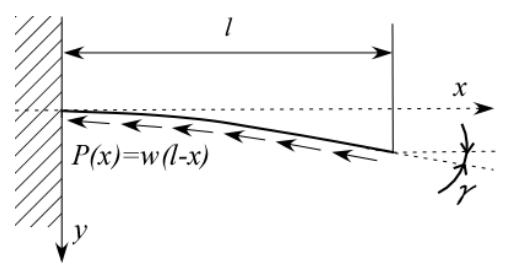

(b) Distributed load

Fig. 1 Modeling on elastic stability of structure

ここで, $l$ ははりの長さ, $P, P(x)$ は, 各々, 集中荷重と分布軸力を示す. また, $w$ ははりの単位長さあた りの分布荷重を示す. $\gamma$ は荷重の作用する角度を示す.

図 1(a) は自由端に集中荷重が作用する場合で, $\gamma=0$ の場合は保存力が作用するモデルとして Euler の問題に対 応する.この $\gamma=0$ の場合は静力学のはりの Euler 座屈である. また, $\gamma>0$ の場合は非保存力が作用する Beck の 問題となる. 一方, 図 1(b) は接線方向の一様分布荷重が作用する場合であり, $\gamma=0$ の場合ははりがたわむ前の状 態の軸方向に作用寸る一様分布荷重となり，保存力が作用するモデルとして Euler の問題となる. また， $\gamma>0$ の 場合ははりの接線方向に従動力として作用寸る一様分布荷重となり, 非保存力が作用するモデルとして Leipholz の問題となる.

\section{$2 \cdot 22$ 自由度の離散化モデリング}

保存力と非保存力（従動力）が作用するモデルについて, Ziegler ${ }^{(2)}$ よると一様はりの連続体モデルの代わりに 2 自由度の離散系でモデリングされる. それらは，それぞれ Euler model，Herrmann model と呼ぶことにし，図 2 のようになる.

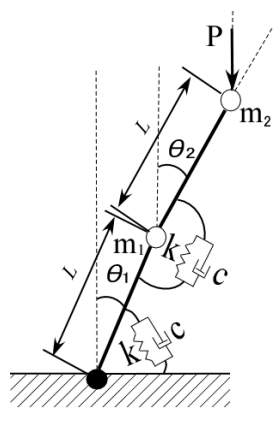

(a) Euler model

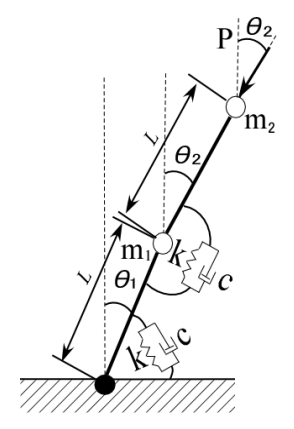

(b) Herrmann model

Fig. 2 Discrete model of two-degree-of-freedom 
この図 2 の 2 自由度モデルは, 弾性はりを 2 本の剛体はりとばねおよびダンパーで近似したものであり, 質点 同士をつなぐ棒に質量は無いものとしている.ここで, 図 2 における $m_{1}, m_{2}$ は集中質量, $L$ ははりの長さ, $\theta_{1}, \theta_{2}$ は角度変化である. また， $k$ は回転ばね定数， $c$ は回転粘性減衰係数である.

\section{$2 \cdot 3$ 連続体モデルと 2 自由度離散化モデルの力学的な等価性}

図 1 の連続体モデルを分割して，図2 のような 2 自由度の離散化モデルを作成する場合の両者の関係を求める. 図 3(a) の連続体モデルを 図3(b) に示すように 3 分割し，2 ヶ所の分割点で回転ばねにより連結されているとす る. そして, 各連結されているはりは剛体のはりとする.いま, 曲げモーメント $M$ が図 3(a) の片持ちはりの 自由端に作用した場合の回転角 $\phi$ は, 構造力学より

$$
M=\frac{E I}{l} \phi
$$

である.ここで，lは片持ちはりの長さである.

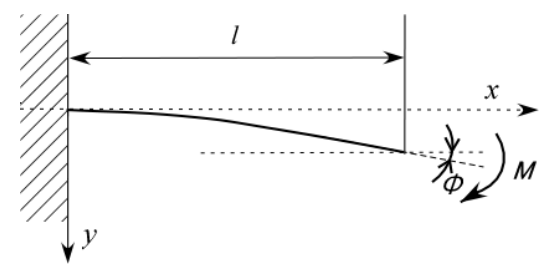

(a) Continuous model

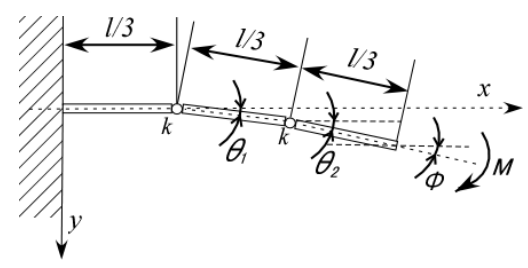

(b) Discrete model

Fig. 3 Discretization of continuous model

一方，図3(b) の3分割された離散化モデルにも，図に示すように，曲げモーメント $M$ がこの自由端に作用す るとする. このときの 3 分割された剛体はりの各連結点の回転角 $\theta_{1}, \theta_{2}$ と曲げモーメント $M$ の間には次の関 係式が成り立つ.

$$
M=k \theta_{1}, \quad M=k\left(\theta_{2}-\theta_{1}\right)
$$

ここで, 図 3(b) より, はりの自由端の回転角 $\phi$ は, 剛体はりの右側の連結点の回転角 $\theta_{2}$ に等しい. この 関係を式(2)に代入すると

$$
M=\frac{k}{2} \phi
$$

となる．離散化モデルと連続体モデルとで，自由端に負荷した同じモーメント $M$ によって，同じ先端の回転角 $\phi$ を生じるようにすると，離散化モデルの各連結点の回転ばね定数 $k$ は次のようになる.

$$
k=\frac{2 E I}{l}
$$

ここで， $E$ はヤング率，I は断面 2 次モーメントである. 次に, 図3(b) と図 2 の比較において $m_{1}, m_{2}$ の 值は, 図 3(b) の3 分割のはりの先端部の半分の質量を $m_{2}$ に集約し, 3 分割のはりの先端部の残り半分と中間 部の半分の合計を $m_{1}$ に集約すると,

$$
m_{1}=\frac{\rho A l}{3}, \quad m_{2}=\frac{\rho A l}{6}
$$

の関係が得られる. ここで $\rho$ は一椂はりの単位長さ当たりの密度, $A$ ははりの断面積である. 以上より, 図 2 の Euler model, Herrmann model の諸元は一様片持ちはりとの力学的な等価性を考えるために, 式(4), (5)の関係を 近似的に採用することにする. また，図 2 のはりの長さは $L=l / 3$ とすればよい.

\section{$2 \cdot 4$ 支配方程式}

$2 \cdot 4 \cdot 1 \quad 2$ 自由度の離散化モデルの先端に集中荷重が作用する場合 
まず，保存力が作用する場合，すなわち Euler model に対応する支配方程式は 図 2(a) のモデルに対して， Lagrange の関係式を用いて計算すると，

$$
\left[\begin{array}{cc}
\left(m_{1}+m_{2}\right) L^{2} & m_{2} L^{2} \\
m_{2} L^{2} & m_{2} L^{2}
\end{array}\right]\left\{\begin{array}{l}
\ddot{\theta}_{1} \\
\ddot{\theta}_{2}
\end{array}\right\}+\left[\begin{array}{cc}
2 c & -c \\
-c & c
\end{array}\right]\left\{\begin{array}{l}
\dot{\theta}_{1} \\
\dot{\theta}_{2}
\end{array}\right\}+\left[\begin{array}{cc}
2 k-P L & -k \\
-k & k-P L
\end{array}\right]\left\{\begin{array}{l}
\theta_{1} \\
\theta_{2}
\end{array}\right\}=\left\{\begin{array}{l}
0 \\
0
\end{array}\right\}
$$

となる.ここで, 連続体モデルとの等価性を保つためには, 式(4), (5)の関係式およびはりの長さの関係式 $L=l / 3$ を式(6)に代入する必要がある.

次に, 非保存力が作用する場合, すなわち Herrmann model に対する支配方程式は 図 2(b) のモデルに対して, 保存力の場合と同様に計算すると,

$$
\left[\begin{array}{cc}
\left(m_{1}+m_{2}\right) L^{2} & m_{2} L^{2} \\
m_{2} L^{2} & m_{2} L^{2}
\end{array}\right]\left\{\begin{array}{l}
\ddot{\theta}_{1} \\
\ddot{\theta}_{2}
\end{array}\right\}+\left[\begin{array}{cc}
2 c & -c \\
-c & c
\end{array}\right]\left\{\begin{array}{l}
\dot{\theta}_{1} \\
\dot{\theta}_{2}
\end{array}\right\}+\left[\begin{array}{cc}
2 k-P L & P L-k \\
-k & k
\end{array}\right]\left\{\begin{array}{l}
\theta_{1} \\
\theta_{2}
\end{array}\right\}=\left\{\begin{array}{l}
0 \\
0
\end{array}\right\}
$$

となる. 保存力の場合と同様に, 連続体モデルとの等価性を保つためには, 式(4), (5)の関係式および長さの関係 式 $L=l / 3$ を式(7)に代入する必要がある.

\section{$2 \cdot 4 \cdot 2$ 連続体モデルの先端に集中荷重が作用する場合}

図 1(a) の片持ちはりモデルに集中荷重 $P$ が作用するとき, $P$ が保存力の場合は Euler 座屈問題となり, 次式 が得られる.

$$
P_{c r}=\frac{\pi^{2} E I}{(2 l)^{2}}
$$

ここで， $P_{c r}$ は座屈荷重である.

次に，非保存力（従動力）の集中荷重 $P$ が作用するときは,

$$
\rho A \frac{\partial^{2} y}{\partial t^{2}}+E I \frac{\partial^{4} y}{\partial x^{4}}+P \frac{\partial^{2} y}{\partial x^{2}}+c \frac{\partial y}{\partial t}=0
$$

となる，ここで，材料減衰や構造減衰による減衰項は第 4 項で表現できるとしている.

このような集中荷重は，例えば軸流中のはりでは流体から受ける圧力抗力や摩擦抗力を，はりの先端に集中さ せて近似した場合と考えられる。

\section{$2 \cdot 4 \cdot 3$ 連続体モデルに一様分布荷重が作用する場合}

図 1(b) のような片持ちはりモデルに軸方向の一様分布荷重 $w$ が作用寸るときの支配方程式は，保存力の場合， 軸力 $P(x)=w(l-x)$ であるので,

$$
\rho A \frac{\partial^{2} y}{\partial t^{2}}+E I \frac{\partial^{4} y}{\partial x^{4}}+w(l-x) \frac{\partial^{2} y}{\partial x^{2}}-w \frac{\partial y}{\partial x}+c \frac{\partial y}{\partial t}=0
$$

となる. 次に, 片持ちはりモデルに接線方向に一様分布荷重 $w$ が作用するときの支配方程式は, 非保存力（従 動力）の場合は

$$
\rho A \frac{\partial^{2} y}{\partial t^{2}}+E I \frac{\partial^{4} y}{\partial x^{4}}+w(l-x) \frac{\partial^{2} y}{\partial x^{2}}+c \frac{\partial y}{\partial t}=0
$$

となる.

このような一様分布荷重は，例えば軸流中のはりでは流体から受ける表面における摩擦に起因する摩擦効力が 主体と考えられる.

\section{$2 \cdot 5$ 数值解法}

本節では，連続体モデルの一様片持ちはりの解をいかに求めるかを述べる. 
流体力を近似して非保存力（従動力）としての接線方向の一様分布荷重が作用する場合について考える.まず, 一様片持ちはりの変位 $y(x, t)$ を, Galerkin 法を応用するため, 境界条件を満足する関数 $\phi_{i}(x)$ の級数展開で, 次式のように表されるとする.

$$
y(x, t)=\sum_{i=1}^{\infty} \phi_{i}(x) q_{i}(t)
$$

ここで， $\phi_{i}(x)$ は一様片持ちはりの境界条件を満足しなければならない. また, $q_{i}(t)$ は時間関数である.

そして，例えば，一様片持ちはりに非保存力（従動力）の接線方向の一様分布荷重が作用寸る場合の支配方程 式である式(11)に，式(12)を代入すると，

$$
\rho A \sum_{i=1}^{\infty} \phi_{i}(x) \ddot{q}_{i}(t)+E I \sum_{i=1}^{\infty} \frac{d^{4} \phi_{i}(x)}{d x^{4}} q_{i}(t)+w(l-x) \sum_{i=1}^{\infty} \frac{d^{2} \phi_{i}(x)}{d x^{2}} q_{i}(t)+c \sum_{i=1}^{\infty} \phi_{i}(x) \dot{q}_{i}(t)=0
$$

となる. いま, 固有関数の $\phi_{i}(x)$ に, 真空中の一様片持ちはりの固有関数を採用すると,

$$
\frac{d^{4} \phi_{i}(x)}{d x^{4}}-\kappa_{i}^{4} \phi_{i}(x)=0
$$

を満足する. ここで, $\kappa_{i}{ }^{4}=\frac{\rho A}{E I} \omega_{i}{ }^{2}$ であり， $\omega_{i}$ は固有関数 $\phi_{i}(x)$ に対応する固有円振動数である. 式(14)の 関係を式(13)に適用して整理すると，

$$
\sum_{i=1}^{\infty} \phi_{i}(x) \ddot{q}_{i}(t)+\frac{c}{\rho A} \sum_{i=1}^{\infty} \phi_{i}(x) \dot{q}_{i}(t)+\left\{\sum_{i=1}^{\infty} \omega_{i}^{2} \phi_{i}(x) q_{i}(t)+\frac{w(l-x)}{\rho A} \sum_{i=1}^{\infty} \frac{d^{2} \phi_{i}(x)}{d x^{2}} q_{i}(t)\right\}=0
$$

となる. そして, 式(15)の両辺に固有円振動数が $\omega_{k}$ である固有関数 $\phi_{k}(x)$ をかけて，はり全長にわたって 0 から $l$ まで積分し，固有関数の直交性を利用すると，

$$
\begin{aligned}
& \left\{\int_{0}^{l} \phi_{k}^{2}(x) d x\right\} \ddot{q}_{k}(t)+\left\{\frac{c}{\rho A} \int_{0}^{l} \phi_{k}^{2}(x) d x\right\} \dot{q}_{k}(t) \\
& \quad+\left\{\omega_{k}^{2}\left(\int_{0}^{l} \phi_{k}^{2}(x) d x\right) q_{k}(t)+\sum_{i=1}^{\infty}\left(\frac{w}{\rho A} \int_{0}^{l}(l-x) \phi_{k}(x) \frac{d^{2} \phi_{i}(x)}{d x^{2}} d x\right) q_{i}(t)\right\}=0 \quad(k=1 \sim \infty)
\end{aligned}
$$

となる. ここで, モードの打ち切りを $n$ とすると, $k=1 \sim n$ となる. 式(16)をマトリックス表示で書き直すと,

$$
\left[\begin{array}{ccc}
\ddots & & 0 \\
& M_{k} & \\
0 & & \ddots
\end{array}\right]\left\{\ddot{q}_{k}(t)\right\}+\left[\begin{array}{ccc}
\ddots & & 0 \\
& C_{k} & \\
0 & & \ddots
\end{array}\right]\left\{\dot{q}_{k}(t)\right\}+\left(\left[\begin{array}{ccc}
\ddots & & 0 \\
& K_{k} & \\
0 & & \ddots
\end{array}\right]+\left[D_{i, k}\right]+\left[E_{i, k}\right]\right)\left\{q_{k}(t)\right\}=0
$$

となる.ここで，

$$
\begin{aligned}
& M_{k}=\int_{0}^{l} \phi_{k}^{2}(x) d x \\
& C_{k}=\frac{c}{\rho A} \int_{0}^{l} \phi_{k}^{2}(x) d x \\
& K_{k}=\omega_{k}^{2} \int_{0}^{l} \phi_{k}^{2}(x) d x \\
& D_{i, k}=\frac{w l}{\rho A} \int_{0}^{l} \phi_{k}(x) \frac{d^{2} \phi_{i}(x)}{d x^{2}} d x \\
& E_{i, k}=\frac{-w}{\rho A} \int_{0}^{l} x \phi_{k}(x) \frac{d^{2} \phi_{i}(x)}{d x^{2}} d x
\end{aligned}
$$


である. 式(17)において一様分布荷重 $w$ を変化させて，複素固有值解析を行い, 根軌跡を求める. 固有值 $\lambda$ の $\operatorname{Re}(\lambda)$ が正で, $\operatorname{Im}(\lambda) \neq 0$ のとき, 振動状態はフラッタとなる. また, $\operatorname{Re}(\lambda)$ が正で, $\operatorname{Im}(\lambda)=0$ のとき, 振 動状態はダイバージェンスとなる，そして，上記では非保存力（従動力）として接線方向の一様分布荷重が作用寸 る場合である式(11)について取り扱ったが，非保存力（従動力）として集中荷重が作用寸る場合である式(9), 保存 力として軸方向の一様分布荷重が作用寸る場合である式(10)についても同様の取り扱いにより, 解が得られる.

\section{3. 解析結果と考察}

\section{$3 \cdot 1$ 数値計算の諸元}

数值計算するはりの物理定数を表 1 に示す. ヤング率は銅に相当する值を用いた. 実験等をすることを考えて 無次元化はしていない.

Table 1 Specifications of a beam

\begin{tabular}{|c|c|c|c|}
\hline$\rho:$ Density $\left[\mathrm{kg} / \mathrm{m}^{3}\right]$ & $8.92 \times 10^{3}$ & $R:$ Radius of beam $[\mathrm{m}]$ & $1.00 \times 10^{-3}$ \\
\hline$E:$ Young modulus $[\mathrm{Pa}]$ & $1.00 \times 10^{11}$ & $l:$ Length of beam $[\mathrm{m}]$ & 1.00 \\
\hline
\end{tabular}

また，はりの断面積, 断面 2 次モーメントは次式を用いる.

$$
A=\pi R^{2}, \quad I=\frac{\pi}{64}(2 R)^{4}
$$

\section{$3 \cdot 22$ 自由度系の離散化モデル}

\section{$3 \cdot 2 \cdot 1$ オイラーモデル(保存力)の場合}

図 4 は Euler model について, 非減衰系と減衰系に関して, その根軌跡を示寸. なお, 非減衰系の場合は根軌跡 の代わりに横軸の荷重と縦軸の固有円振動数の関係を示した. また, 図 5 に, 減衰比を変化させて, 軸荷重と安定, 不安定を支配する根軌跡の実部との関係を示す.

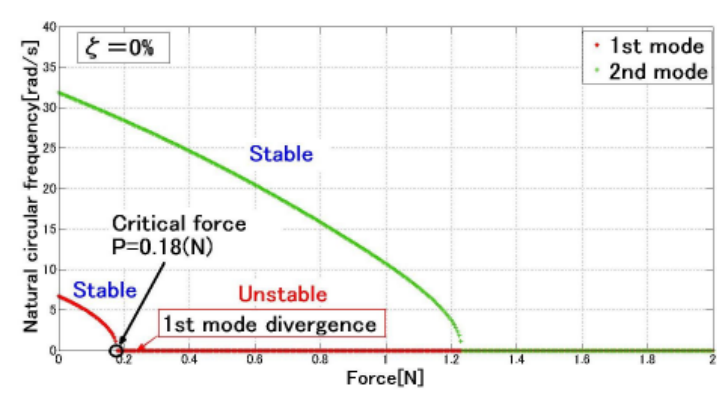

(a) No damping

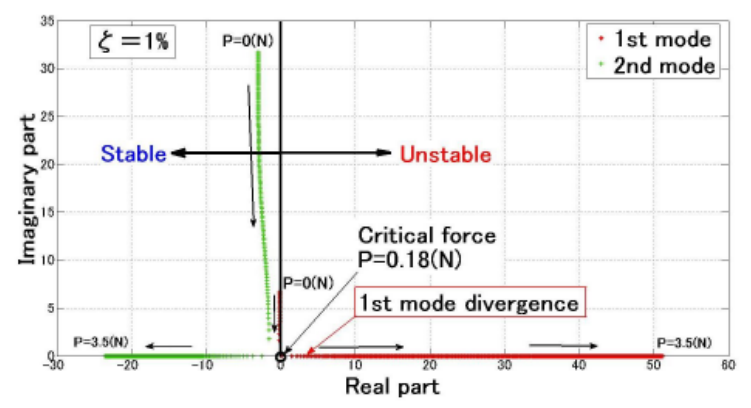

(b) $1 \%$ critical damping

Fig. 4 Euler model

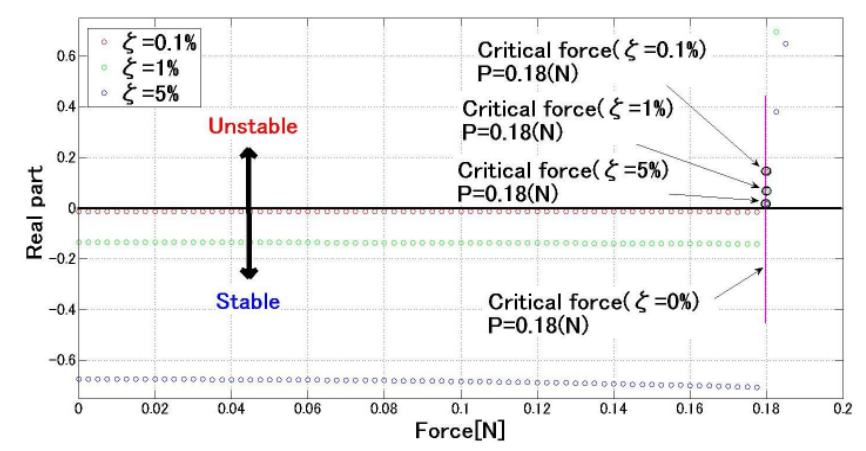

Fig. 5 Effect of damping on instability of Euler model 


\section{$3 \cdot 2 \cdot 2$ ハーマンモデル(非保存力) の場合}

図 6 は Herrmann model について, 非減衰系と減衰系に関して, 同様に根軌跡を示す. 同じく非減衰系の場合は, 根軌跡の代わりに荷重と固有円振動数の関係を示した. また, 図 7 に, 減衰比を変化させて, 軸荷重と根軌跡の 実部との関係を示す.

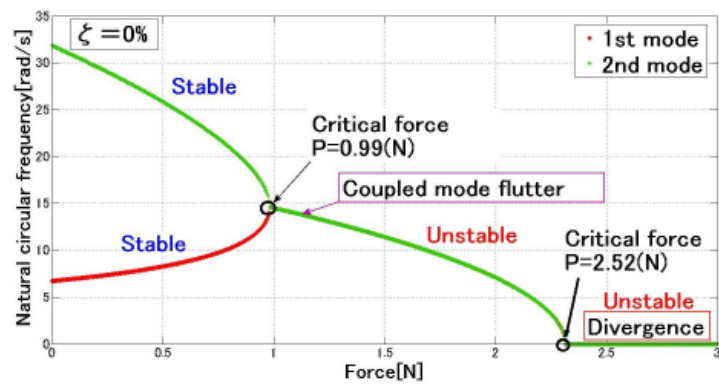

(a) No damping

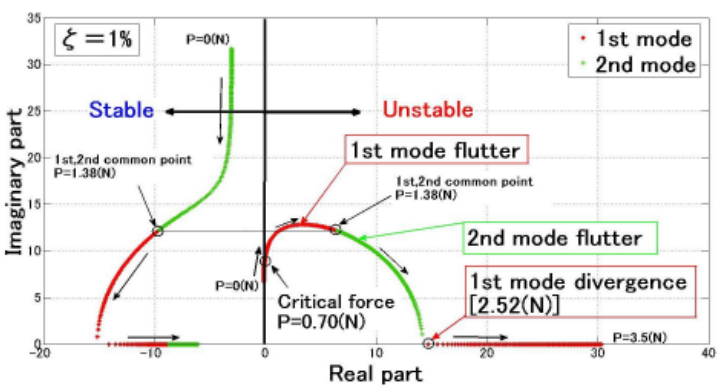

(b) $1 \%$ critical damping

Fig. 6 Herrmann model

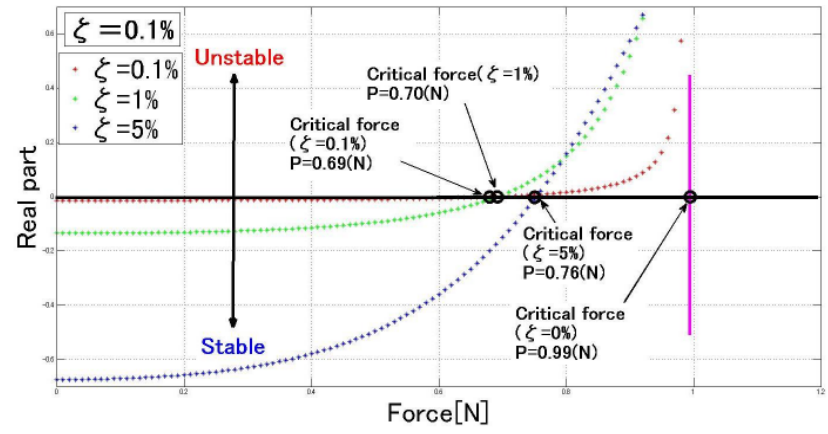

Fig. 7 Effect of damping on instability of Herrmann model

図 5 の Euler model と図 7 の Herrmann model を比較して, Herrmann model では系の減衰の存在が不安定効果 を与えることがわかる。このことをさらに考察するため，図８に Herrmann model のフラッタについて，減衰を 変化させて, 臨界荷重と虚部の関係を検討する. 横軸は荷重を, 縦軸は固有円振動数を表す根軌跡の虚部を示す. 図中に丸印でフラッタの始まりの位置，および 1 次モードと 2 次モードの合体の位置を示す. 図 8 と図 6(a) と を併せて観察すると，非減衰系の場合は，1 次モードと 2 次モードが合体する位置で，フラッタが発生している が，減衰系の場合は，1 次モードの途中でフラッタの開始点が現れることがわかる．すなわち，非減衰系の場合 は，連成モードフラッタを示すが，減衰系の場合は単独モードフラッタを示すことがわかる．このことを，Euler model で検討すると，紙面の関係上図を示していないが，減衰系の場合でも図 4(a) の非減衰系の場合とほとんど 同じであり，減衰の不安定効果は認められない. なお，図中の 1st, 2nd common point は 1 次モードと 2 次モード が合体する位置を示す.

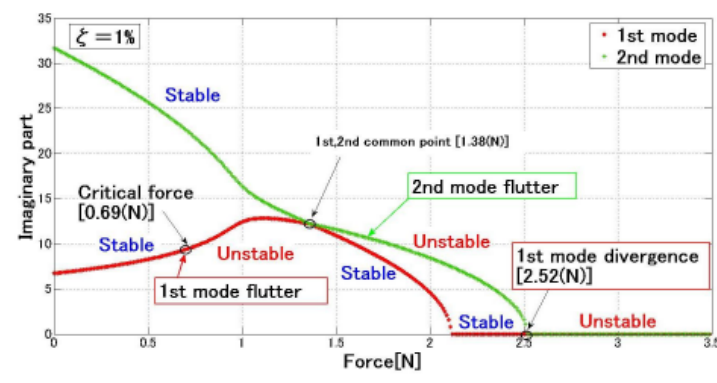

(a) $1 \%$ critical damping

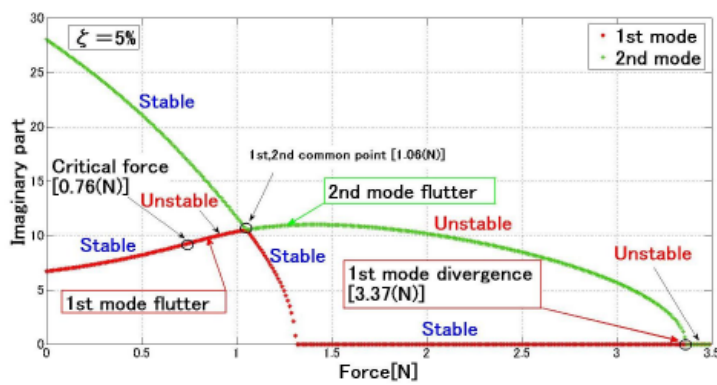

(b) $5 \%$ critical damping

Fig. 8 Relationship between damping and critical load on flutter of Herrmann model 


\section{$3 \cdot 3$ 連続体モデル}

\section{$3 \cdot 3 \cdot 1$ 連続体モデルに集中荷重(保存力)が作用する場合}

いままで示した 2 自由度モデルによる Euler model と Herrmann model の力学的相違について, 連続体モデルに よって考察する. 保存力が作用する連続体モデルの場合は，2 自由度モデルの Euler model に相当する． 2 自由度 モデルと連続体モデルの力学的特性を出来るだけ等価にするため, 2 ・3 節で述べたモデリングを行っている.

Euler model に相当する場合は，いわゆる構造力学の Euler 座屈である. $2 \cdot \mathbf{4} \cdot \mathbf{2}$ 節の式(8)を用いて座屈荷重を 算出すると, $P_{c r}=0.18$ となる.

\section{$3 \cdot 3 \cdot 2$ 連続体モデルに集中荷重(非保存力)が作用する場合}

非保存力（従動力）が作用する連続体モデルの場合は，2 自由度モデルの Herrmann model に相当する. 図 9 に 非減衰系と減衰系についての根軌跡を示す。同じく非減衰の場合は, 根軌跡の代わりに荷重と固有円振動数の関 係を示す．図７と同様に，図 10 に，減衰比を変化させて，集中荷重と根軌跡の実部との関係を示す，なお，図 9(a) の曲線が縦軸と交差する值は, 荷重が零のときの連続体モデルの 1 次と 2 次の固有円振動数を示す.例えば, 図 4(a) のこれに相当する場合と比較すると, わずかな相違が認められる.これは連続体の解析解と 2 自由度の離 散化モデルとの間のモデリングの精度の差を示す.

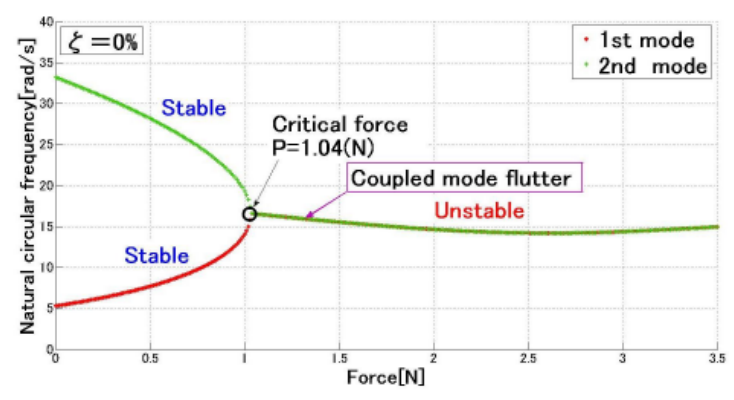

(a) No damping

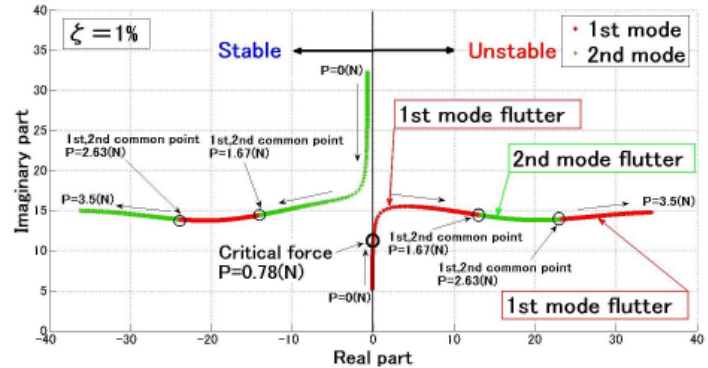

(b) $1 \%$ critical damping

Fig. 9 Continuous model subjected to concentrated load as nonconservative system

図 7 と図 10 を比較すると, 2 自由度モデルでも連続体モデルでも, 非保存力が作用する系では系の減衰の存 在が不安定効果を与えることがわかる. 同様に, このことをさらに考察するため, 図 11 に連続体モデルの非保 存力が作用する系のフラッタについて, 減衰を変化させて, 臨界荷重と虚部の関係を検討する，横軸は荷重を, 縦軸は固有円振動数を表す根軌跡の虚部を示寸，図 11 と図 9(a) とを併せて観察すると，やはり，非減衰系の場 合は, 1 次モードと 2 次モードの合体の位置で, 連成モードフラッタが発生しているが, 減衰系の場合は, 1 次モ ードの途中で単独モードフラッタが現れることがわかる．これらのモードの変化をフラッタの発生前後で比較す ると図 12 となる. なお，これらの連続体モデルでの数值計算のモードの打ち切りの次数は，10 とした．これ以 降に示寸数值計算においても同様である.

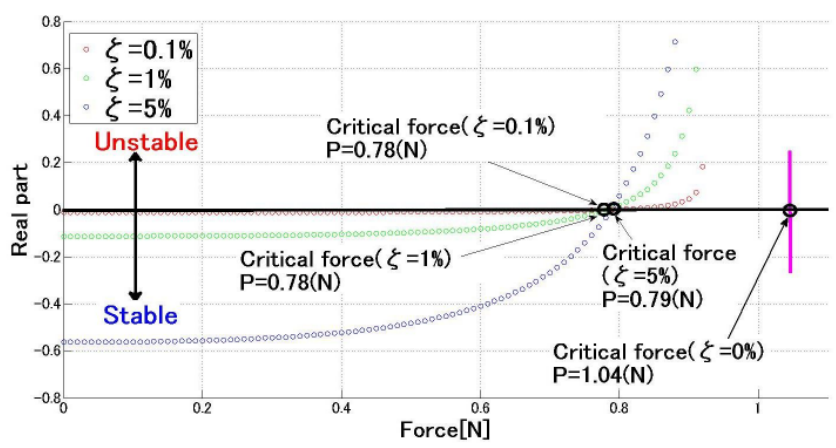

Fig. 10 Effect of damping on instability of continuous model subjected to concentrated load as nonconservative system 


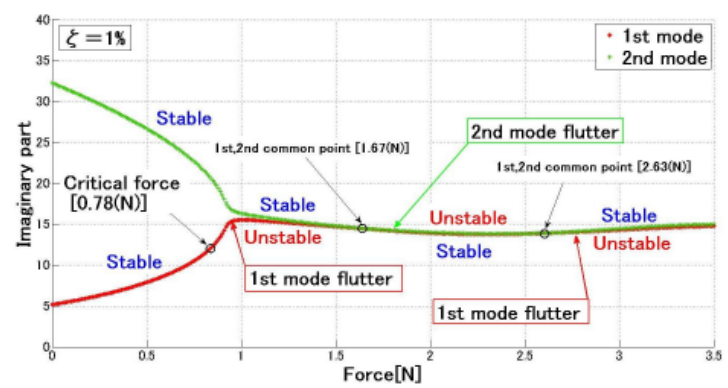

(a) $1 \%$ critical damping

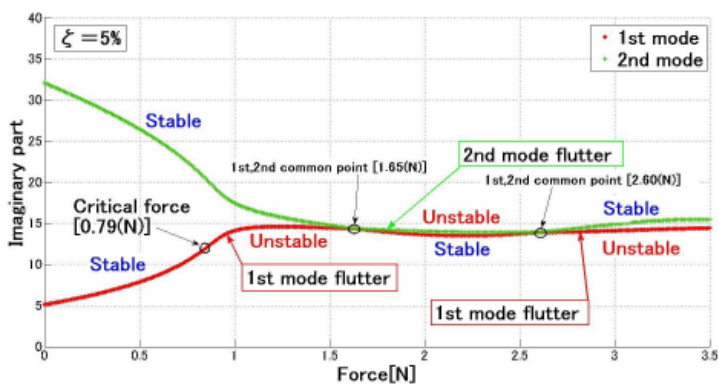

(b) $5 \%$ critical damping

Fig. 11 Relationship between damping and critical load on flutter of continuous model subjected to concentrated load as nonconservative system

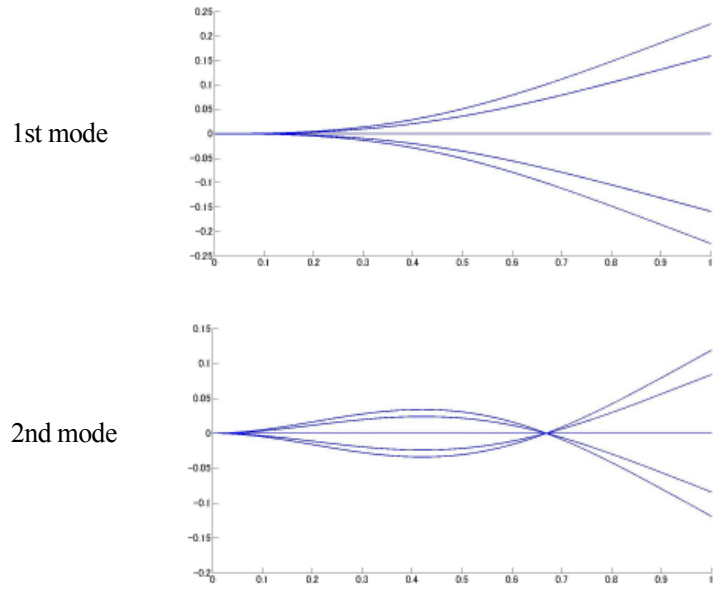

Stable, $\quad P=0.7 \mathrm{~N}$

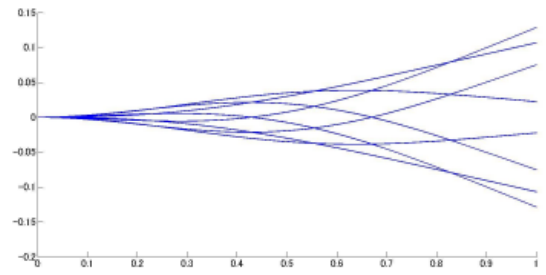

Unstable (flutter), $\quad P=1.2 \mathrm{~N}$

(a) Coupled mode flutter (Undamped system)

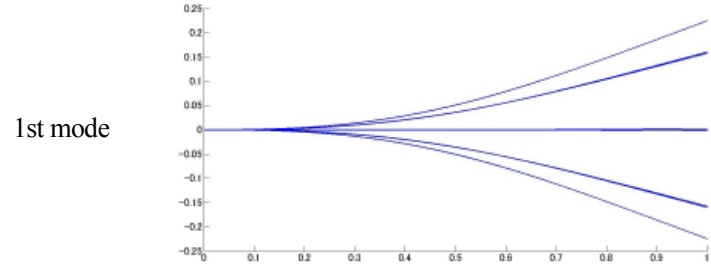

Stable, $P=0.7 \mathrm{~N}$

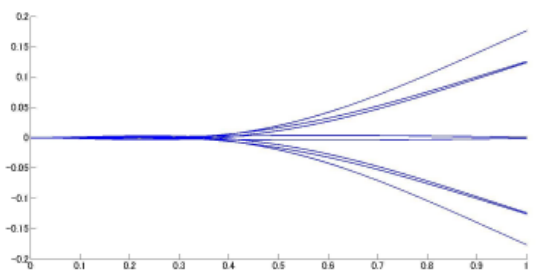

Unstable (flutter), $\quad P=0.9 \mathrm{~N}$

(b) Single mode flutter (Damped system, 1\% of critical damping)

Fig. 12 Mode shape before and after flutter of continuous model subjected to concentrated load as nonconservative system

\section{$3 \cdot 3 \cdot 3$ 連続体モデルに一様分布荷重 (非保存力)が作用する場合}

非保存力（従動力）の一様分布荷重が，はりの接線方向に作用する場合に関して，図 13 に非減衰系と減衰系 についての根軌跡を示す. 同じく非減衰の場合は, 根軌跡の代わりに荷重と固有円振動数の関係を示す. 図 9 の 集中荷重の場合と同様の傾向が認められる. 


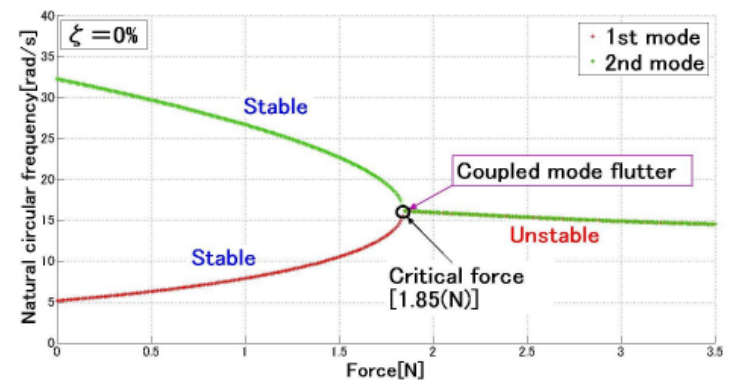

(a) No damping

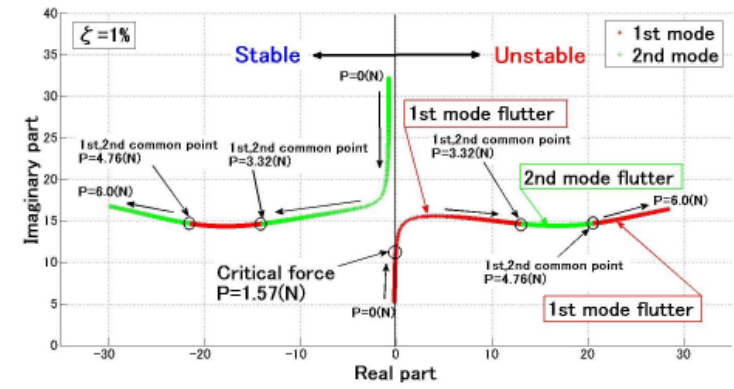

(b) $1 \%$ critical damping

Fig. 13 Continuous model subjected to distributed load as nonconservative system

\section{4. 結 語}

(1) 保存力が作用する系と非保存力が作用する系に関して, 離散化モデルである Euler モデルと Herrmann モデル に対応する連続体モデルの数值解を提案し, 両者の物理的整合性を示した。連続体モデルと離散化モデルは低い 荷重では良い一致を示すが，高い荷重では，非保存力が作用する場合，離散化モデルではフラッタからダイバー ジェンスに変化するが，連続体モデルでは引き続き 1 次モードと 2 次モードが離れずに連成モードフラッタ状態 を保つこと等の相違が認められた.

(2) 軸方向圧縮力を受ける片持ちはりの場合, 流体力を保存力と扱うとき, 最初にダイバージェンスが現れるが, 非保存力と扱うとき，限界荷重は高くなるが，最初にフラッタが現れることを確認した．また，非保存力が作用 寸る系における減衰の不安定効果が認められることを示し, 非減衰系では連成モードフラッタが生じ, 減衰系で は単独モードフラッタが生じることを確認した，さらに，これらについて，フラッタ発生前後のモード変化の相 違について明らかにした。

（3）分布荷重が作用する場合も，集中荷重の場合と同様の動的不安定効果を示すことを確認した.

\section{謝 辞}

本研究をまとめるに当たり, 大阪市立大学大学院工学研究科の川合忠雄教授に大変お世話になった. ここに深 く謝意を表します。

\section{文献}

(1) Bolotin, V. V., "Nonconservative Problems of the Theory of Elastic Stabilities, Pergamon press (1963).

(2) Ziegler, H., "Principles of Structural Stability”, Blaisdell Publishing Company, A Division of Ginn and Company (1968).

（3）近藤誠治, 中田和夫共訳, “ボローチン原著, 弾性系の動的安定”, コロナ社 (1972).

(4) Leipholz, H., "Stability of elastic systems", The Universities Press, Belfast, Samsom-Sijthoff, Alphen aan den Rijn (1980).

(5) 杉山吉彦, 関谷壮, “非保存的弾性系の安定問題”, 日本機械学会誌, Vol. 73, No. 620 (1970), pp.1238-1245.

(6) 本間俊雄, 登坂宣好, “積分方程式法による保存力・非保存力を受ける弾性棒の動的安定解析”, 日本機械学会論文集 A 編, Vol. 63, No. 614 (1997), pp.2180-2187.

(7) Langthjem, A. M., "Optimum Design of Cantilevered Columns Subjected to Non-conservative Loading by Rocket Thrust", Doctoral Thesis at Osaka Prefecture University (2002).

(8) Kounadis, A. N., Gantes, and C. j., Bolotin, V. V., "An Improved Energy Criterion for Dynamic Buckling of Imperfection Sensitive Nonconservative Systems", International Journal of Solids and Structures, Vol. 38 (2001), pp.7487-7500.

(9) Schmid, P. J., Langre, E. de., "Transient Growth Before Coupled-Mode Flutter", Transactions of the ASME, Journal of Applied Mechanics, Vol. 70 (2003), pp.894-901.

(10) Fazelzadeh, S. A., Kalantani, H., and Mazidi, A., "Aeroelastic Instability of Bending-Torsion Wings Containing a Mass Subjected to Follower Force", Proc. of the $9^{\text {th }}$ International Conference on Flow-Induced Vibration (2008), pp.477-482. 